PUBLIK: Jurnal Manajemen Sumber Daya Manusia, Adminsitrasi dan Pelayanan Publik Sekolah Tinggi Ilmu Administrasi Bina Taruna Gorontalo

Volume VII Nomor 22020

\title{
PENGARUH PEREKRUTAN DAN TRAINING, PEMBERIAN TANGGUNG JAWAB, KOMPENSASI, DAN PROMOSI TERHADAP EFEKTIVITAS KINERJA KARYAWAN
}

\author{
Christine Herawati Limbong1; Bhakti Helvi Rambe²; Yudi Prayoga ${ }^{3}$; \\ Mulya Rafika ${ }^{4}$; Dinda Karansita Hasibuan ${ }^{5}$ \\ ${ }^{12345}$ Universitas Labuhanbatu \\ christinehera63@gmail.com ${ }^{1}$; bhaktihelvirambe@gmail.com ${ }^{2}$; prayogayudi03@gmail.com ${ }^{3}$; \\ mulya_rafika@yahoo.co.id ${ }^{4}$; dindacantik7877@gmail.com ${ }^{5}$
}

\begin{abstract}
ABSTRAK
Penelitian ini bertujuan untuk menguji secara empiris tentang pengaruh perekrutan dan training, pemberian tanggung jawab, kompensasi, dan promosi terhadap efektivitas kinerja karyawan. Pada penelitian ini peneliti menghubungkan antara keempat variabel. Pengambilan sampel dilakukan dengan menggunakan metode purposive sampling dan dalam penelitian ini penulis mengambil sampel dari PT. Pertani (Persero) Kantor Cabang Sumatera Utara dengan jumlah sampel sebanyak 30 orang. Metode penelitian yang dilakukan dengan menyebarkan kuisioner. Teknik analisa data pada penelitian ini menggunakan analisis regresi berganda. Pada uji validitas data untuk setiap variabel dinyatakan valid, hal ini dapat dilihat bahwa keempat variabel lebih besar ( $>$ ) dari 0,30. Dan untuk uji reabilitas data untuk setiap variabel juga dinyatakan realibel atau handal, hal ini juga dapat dilihat bahwa keempat variabel lebih besar (>) dari 0,60. Pada uji hipotesis untuk uji simultan (uji F) diperoleh nilai probabilitas $F$ sebesar 0,011 dimana $0,011<0,05$, yang artinya bahwa perekrutan dan training, pemberian tanggung jawab, kompensasi, dan promosi berpengaruh signifikan terhadap efektivitas kinerja karyawan. Sedangkan untuk uji parsial (t) diperoleh hasil bahwa untuk keempat variabel ini memiliki pengaruh signifikan terhadap efektivitas kinerja karyawan pada PT Pertani (Persero) Kantor Cabang Pemasaran Sumatera Utara.
\end{abstract}

\section{Kata Kunci: Perekrutan; Pelatihan; Tanggung Jawab; Kompensasi; Promosi; Efektifitas Kinerja}

\begin{abstract}
This study aims to test empirically the effect of recruitment and training, giving responsibility, compensation, and promotion on the effectiveness of employee performance. In this study, researchers connected the four variables. Sampling was done using purposive sampling method and in this study the authors took samples from PT. Pertani (Persero) Branch Office of North Sumatra with a sample size of 30 people. The research method is carried out by distributing questionnaires. The data analysis technique in this study uses multiple regression analysis. In the data validity test for each variable is declared valid, it can be seen that the four variables are greater (>) than 0.30. And to test the reliability of the data for each variable is also stated to be reliable or reliable, it can also be seen that the four variables are greater (>) than 0.60. In the hypothesis test for the simultaneous test ( $F$ test), the probability value of $F$ is 0.011 where $0.011<0.05$, which means that
\end{abstract}


recruitment and training, giving responsibility, compensation, and promotion have a significant effect on the effectiveness of employee performance. As for the partial test ( $t)$, the results show that these four variables have a significant effect on the effectiveness of employee performance at PT Pertani (Persero), Branch Marketing Office of North Sumatra.

Keywords: Recruitment; Training; Responsible; Compensation; Promotion; Performance Effectiveness

\section{PENDAHULUAN}

Berkembangnya perekonomian Indonesia di era globalisasi, setiap perusahaan di tuntut untuk dapat meningkatkan segala sesuatu yang berkaitan dengan kegiatan operasional perusahaan, mulai dari perencanaan operasional perusahaan sampai bagaimana pengendalian yang harus dilakukan. Dalam hal ini peranan SDM tidak kalah penting dari sumber daya lainnya, misalnya sumber daya alam. SDM manusia adalah potensi yang terkandung dalam diri manusia untuk mewujudkan perannya sebagai makhluk sosial yang mampu mengelola dirinya sendiri serta seluruh potensi yang terkandung di alam menuju tercapainya kesejahteraan kehidupan dalam tatanan yang seimbang dan berkelanjutan.

Tumbuh dan berkembangnya suatu perusahaan tergantung pada Sumber Daya Manusia (SDM) yang cakap dan ahli di bidangnya. Dalam hal ini peranan SDM tidak kalah penting dari sumber daya lainnya, misalnya sumber daya alam. SDM adalah potensi yang terkandung dalam diri manusia untuk mewujudkan perannya sebagai makhluk sosial yang mampu mengelola dirinya sendiri serta seluruh potensi yang terkandung di alam menuju tercapainya kesejahteraan kehidupan dalam tatanan yang seimbang dan berkelanjutan. Dalam pengertian praktis sehari-hari, SDM lebih dimengerti sebagai bagian dari sistem yang membentuk suatu organisasi yang mengelola sumberdaya alam (SDA).

Dewasa ini, perkembangan terbaru memandang SDM bukan sebagai sumber daya belaka, melainkan lebih berupa modal atau aset bagi institusi atau organisasi. Karena itu kemudian muncullah istilah baru di luar H.R. (Human Resources), yaitu H.C. atau Human Capital. Di sini SDM dilihat bukan sekedar sebagai aset utama, tetapi aset yang bernilai dan dapat dilipat gandakan, dikembangkan dan juga bukan sebaliknya sebagai beban dalam perusahaan. Keberadaan SDM di dalam suatu perusahaan memegang peranan sangat penting. Tenaga kerja memiliki potensi yang besar untuk menjalankan aktivitas perusahaan. Potensi setiap SDM yang ada dalam perusahaan harus dapat dimanfaatkan dengan sebaik-baiknya sehingga mampu memberikan output optimal. 
Dalam meningkatkan kinerja karyawannya perusahaan menempuh beberapa cara misalnya melalui pendidikan, pelatihan, pemberian kompensasi yang layak, menciptakan lingkungan kerja yang kondusif dan pemberian motivasi. Melalui prosesproses tersebut, karyawan diharapkan akan lebih memaksimalkan tanggung jawab atas pekerjaan mereka karena para karyawan telah terbekali oleh pendidikan dan pelatihan yang tentu berkaitan dengan implementasi kerja mereka. Sedangkan pemberian kompensasi, lingkungan kerja yang baik serta pemberian motivasi pada dasarnya adalah hak para karyawan dan merupakan kewajiban dari pihak perusahaan untuk mendukung kontribusi para karyawannya dalam rangka mencapai tujuan yang telah ditentukan.

Seiring dengan berkembangnya perekonomian Indonesia di era globalisasi, setiap perusahaan dituntut untuk dapat meningkatkan segala sesuatu yang berkaitan dengan kegiatan operasional perusahaan, mulai dari perencanaan operasional perusahaan sampai bagaimana pengendalian yang harus dilakukan. Berkembangnya perekonomian pada saat ini, mewajibkan setiap perusahaan untuk dapat melihat peluang usaha bisnis jauh ke depannya. PT Pertani (Persero) Kantor Cabang Pemasaran Sumatera, proses perekrutan dan training, pemberian tanggung jawab, kompensasi, dan promosi terhadap efektivitas kinerja karyawan, sehingga karyawan agar adanya standarnya cara sistem rekrutmen karyawan supaya mendapat calon karyawan yang berkualitas di bidangnya.

Menurut (Kaswan, 2012), "SDM menjadi keunggulan kompetitif karena beberapa alasan yaitu: Pertama, SDM merupakan satu-satunya sumberdaya yang tidak dapat ditiru oleh pesaing, dan satu-satunya sumber daya yang dapar mensinergikan yaitu menghasilkan output yang nilainya lebih besar. Kedua, keunggulan kompetitif berasal dari tenaga kerja yang sangat produktif, memiliki motivasi tinggi dan terpadu”.

Menurut (Pambudu, 2014), "efektivitas kerja adalah suatu keadaan yang menunjukkan tingkat keberhasilan kegiatan manajemen dalam mencapai tujuan manajemen yang efektif disertai dengan manajemen yang efesien".Untuk menjalankan fungsi efektifivitas kinerja karyawan sangat diperlukan adanya kegiatan-kegiatan atau proses manajemen sumber daya manusia yaitu: Perekrutan dan Training; (2) Pemberian Tanggung Jawab; (3) Kompensasi; (4) Promosi.

\section{PERMASALAHAN}

Penelitian ini bertujuan untuk menguji secara empiris tentang pengaruh perekrutan dan training, pemberian 
tanggung jawab, kompensasi, dan promosi terhadap efektivitas kinerja karyawan di PT. Pertani (Persero) Kantor Cabang Sumatera Utara, baik parsial maupun simultan.

\section{METODE PENELITIAN}

Dalam melakukan penelitian ini peneliti memilih jenis penelitian survey dengan pendekatan kuantitatif, yaitu penelitian yang menggunakan kata-kata atau kalimat dan gambar serta angkaangka dengan memakai sampel dan menggunakan kuesioner sebagai alat pengumpulan data pokok.

(Nurdin \& Hartati, 2019) penelitian deskriptif dimaksud membuat penerimaan penyandaran secara sistematis, faktual, dan akurat mengenai fakta-fakta dan sifatsifat tertentu. Menurut (Sugiyono, 2014) metode penelitian kuantitatif dapat diartikan sebagai metode penelitian yang berlandaskan pada filsafat positivisme, digunakan untuk meneliti pada populas atau sampel tertentu, pengumpulan data menggunakan instrumen penelitian, analisis data bersifat: Yang dijadikan sampel oleh penulis adalah hanya karyawan tetap yang berjumlah 30 orang.

\section{Teknik Pengumpulan Data}

Observasi, yakni kegiatan pengamatan terhadap budaya organisasi dan kinerja pegawai. Observasi atau pengamatan merupakan alat pelengkap di dalam penghimpunan data penelitian.
Menurut Nisbet dan Watt (Sugiyono, 2014) di dalam melakukan pengamatan harus menggunakan catatan tak berstruktur dalam tahap pertama yang terbuka, dalam tahap kedua memberikan perhatian pada sejumlah kategori terpilih.

Wawancara adalah suatu teknik pengumpulan informasi dengan tekhnik bertanya yang bebas, tetapi berdasarkan suatu pedoman (sesuai dengan ruang lingkup penelitian) guna mendapatkan informasi yang dibutuhkan. Wawancara ini mempergunakan pedoman wawancara berstruktur yakni menggunakan pedoman wawancara dimaksudkan untuk memperoleh informasi sebanyak mungkin mengenai permasalahan yang diamati. Kuesioner adalah teknik pengambilan data dengan membuat daftar pertanyaan yang diberikan pada anggota sampel yang bersedia memberikan respons (responden) atau jawaban.

\section{Metode Analisis Data}

Untuk memastikan sub-sub variabel apakah ada pengaruh fungsi perekrutan dan training $(\mathrm{X})$ yang tediri dari pemberian tanggung jawab (X1), konpensasi (X2), dan promosi (X3) terhadap efektivitas kinerja karyawan (Y), maka pengujian dilakukan dengan uji analisis jalur (Path Analisys), dengan terlebih dahulu mengkonversi data skala ordinal ke skala interval melalui Method Successive Interval (MSI). Analisis jalur digunakan dengan pertimbangan bahwa 
pola hubungan antarvariabel dalam penelitian adalah bersifat korelatif dan kausalitas. Data yang terkumpul dianalisis hubungan kausalnya antara subsub variabel yang dilakukan dengan menggunakan anlisis jalur (path analisys) yang memperlihatkan pengaruh. Gambar di atas juga memperlihatkan bahwa subsub variabel tersebut tidak hanya dipengaruhi oleh $\mathrm{X} 1, \mathrm{X} 2$, dan $\mathrm{X} 3$ tetapi ada variabel epselon $(\varepsilon)$ yaitu variabel yang tidak diukur dan diteliti.

\section{TINJAUAN LITERATUR}

\section{A. EFEKTIVITAS DAN KINERJA}

Pada umumnya efektivitas sering dihubungkan dengan efisiensi dalam pencapaian tujuan perusahaan. Padahal suatu tujuan atau saran yang telah tercapai sesuai dengan rencana dapat dikatakan efektif, tetapi belum tentu efisien. Walaupun terjadi suatu peningkatan efektivitas dalam suatu perusahaan maka belum tentu itu efisien. Jelasnya, jika sasaran atau tujuan telah tercapai sesuai dengan yang direncanakan sebelumnya dapat dikatakan efektif.

(Liliweri, 2017), "efektivitas adalah komunikasi yang prosesnya mencapai tujuan yang direncanakan sesuai dengan biaya yang dianggarkan, waktu yang ditetapkan dan jumlah personil yang ditentukan".
Etzioni dalam Tangkilisan (2005), "efektivitas adalah tingkat sejauh mana suatu organisasi yang merupakan sIstem sosial dengan segala sumber daya dan sarana tertentu yang tersedia memenuhi tujuan-tujuannya tanpa pemborosan dan menghindari ketegangan yang tidak perlu di antara anggota-anggotanya".

Mangkunegara (2004), "kinerja adalah hasil kerja secara kualitas dan kuantitas yang dicapai oleh seorang pegawai dalam melaksanakan tugasnya sesuai dengan tanggung jawab yang diberikan kepadanya".

Veizal Rivai (2005), “kinerja merupakan perilaku yang nyata yang ditampilkan setiap orang sebagai prestasi kerja yang dihasilkan oleh karyawan sesuai dengan perannya dalam perusahaan".

\section{a. Tujuan dan Manfaat Penilaian} Kinerja

1) Tujuan Penilaian Kinerja

Menurut Rivai (2005), "penilaian kinerja digunakan untuk berbagai tujuan dalam organisasi. Setiap organisasi menekankan pada tujuan yang berbeda-beda dan organisasi lain dapat juga menekanan tujuan yang berbeda dengan sistem penilaian yang sama. Penilaian kinerja banyak digunakan untuk meningkatkan

kinerja, 
menetapkan tujuan organisasi, mengidentifikasi pelatihan dan kebutuhan pengembangan.

2) Manfaat Penilaian Kinerja

Manfaat penilaian kinerja adalah:

a) Manfaat bagi karyawan: Meningkatkan motivasi dan kepuasan kerja, umpan balik dari kinerja lalu, adanya kesempatan untuk berkomunikasi ke atas.

b) Manfaat bagi penilai (supervisor/manajer) ialah : peningkatan kepuasan kerja, pemahaman yang lebih baik terhadap aspirasi karyawan, sarana meningkatkan motivasi karyawan.

c) Manfaat bagi perusahaan ialah: Meningkatkan kualitas komunikasi, meningkatkan motivasi karyawan secara keseluruhan, meningkatkan pandangan secara luas menyangkut tugas yang dilakukan karyawan. (Rivai,2005)

\section{b. Aspek-aspek Standar Kinerja}

Menurut Mangkunegara (2004), adapun aspek-aspek standar kinerja terdiri dari aspek kuantitatif dan aspek kualitatif.
1) Aspek Kuantitatif terdiri dari: keadaan lingkungan kerja, waktu yang digunakan, pemberian pelayanan dalam bekerja.

2) Aspek Kualitatif terdiri dari: ketepatan kerja dan kualitas pekerjaan, kemampuan dalam bekerja, kemampuan menganalisis data atau informasi, kemampuan mengevaluasi (keluhan).

c. Ukuran Efektivitas Kinerja

Keluaran (output) yang dihasilkan lebih banyak bersifat keluaran (output) tidak berwujud (intangible) yang tidak mudah untuk dikuantifikasi, maka pengukuran efektivitas sering menghadapi kesulitan. Kesulitan dalam pengukuran efektivitas tersebut karena pencapaian hasil (outcome) seringkali tidak dapat diketahui dalam jangka pendek, akan tetapi dalam jangka panjang setelah program berhasil, sehingga ukuran efektivitas biasanya dinyatakan secara kualitatif (berdasarkan pada mutu) dalam bentuk pernyataan saja (judgement), artinya apabila mutu yang dihasilkan baik, maka efektivitasnya baik pula.

Pengukuran efektivitas mutlak dilakukan pada sebuah organisasi 
untuk mengukur sejauh mana langkah efesiensi dilakukan dalam organisasi tersebut. Untuk pengukuran efektivitas suatu organisasi, dapat dilihat dari beberapa kriteria yang terpenuhi yaitu:

a) Input.

Inputmerupakan dasar dari sesuatu yang akan diwujudkan atau dilaksanakan yang berpengaruh pada hasil.

b) Proses Produksi.

Efektivitas dapat diwujudkan apabila memperlihatkan proses produksi yang mempunyai kualitas karena dapat berpengaruh pada kualitas hasil yang akan dicapai secara keseluruhan. Proses produksi menggambarkan bagaimana proses pengembangan suatu hal yang dapat berpengaruh terhadap hasil.

c) Hasil.

Hasil berupa kuantitas atau bentuk fisik dari kerja kelompok atau organisasi. Hasil yang dimaksudkan dapat dilihat dari perbandingan antara masukan (Input) dan keluaran, usaha dan hasil, presentase pencapaian program kerja dan sebagainya.

d) Produktivitas.
Produktivitas adalah bagaimana menghasilkan atau meningkatkan hasil barang dan jasa setinggi mungkin dengan memanfaatkan sumber daya secara efisien, produktivitas berpengaruh pada efektivitas yang berorientasi pada keluaran atau hasil. Produktivitas mencakup pendapatan, pendidikan dan motivasi.

\section{B. PEREKRUTAN DAN TRAINING}

1. PEREKRUTAN

Prosedur perekrutan (recruitment) pada dasarnya merupakan proses untuk memperoleh tenaga kerja yang kompeten seta memiliki performance sesuai dengan bidangnya. Perekrutan didasarkan atas dasar kebutuhan departemen yang telah disetujui oleh pimpinan puncak, dan kebutuhan tersebut mengacu pada standar yang sudah ditetapkam berdasarkan analisa jabatan yang telah dituangkan dalam uraian pekerjaan (job description).

Menurut Mondy (2008:132), "perekrutan adalah proses menarik orang-orang pada waktu yang tepat, dalam jumlah yang cukup dan dengan persyaratan yang 
layak, untuk mengisi lowongan dalam organisasi".

Sedangkan menurut

Hanggraeni (2012:53), "perekrutan adalah menemukan dan menarik pelamar yang memiliki keahlian untuk menduduki posisi tertentu di dalam organisasi".

\section{a) Metode Perekrutan}

Kebanyakan lowongan pekerjaan diisi dengan orang dari dalam perusahaan dan posisi lainnya sangat mungkin diisi dari sumber luar. Metode rekrutmen dari dalam meliputi penempatan pekerjaan, inventarisasi keahlian, penawaran pekerjaan, dan rekomendasi karyawan. Sedangkan rekrutmen dari luar mencakup dari kalangan lembaga penggunaan advertensi dan agen biro pencari kerja. Pada tabel berikut dapat dilihat keunggulan dan kelemahan dari kedua metode rekrutmen tersebut:

Keunggulan dan Kelemahan Rekrutmen Karyawan

\begin{tabular}{|c|c|}
\hline Perek & Perekrutan Eksternal \\
\hline $\begin{array}{l}\text { Keunggulan: } \\
\text { 1. Karyawan telah familiar dengan } \\
\text { perusahan } \\
\text { 2. Biaya rekrutmen dan pelatihan lebih } \\
\text { rendah } \\
\text { 3. Meningkatkan moral dan motivasi } \\
\text { karyawan } \\
\text { 4. Peluang berhasil, karena penilaian } \\
\text { kemampuan dan keahlian lebih tepat. }\end{array}$ & $\begin{array}{l}\text { 1. Memiliki gagasan dan pendekatan } \\
\text { baru } \\
\text { 2. Bekerja mulai dengan lembaran } \\
\text { bersih dan memperhatikan } \\
\text { spesifikasi pengalaman } \\
\text { 3. Tingkat pengetahuan dan keahlian } \\
\text { tidak tersedia dalam perusahaan } \\
\text { yang sekarang }\end{array}$ \\
\hline $\begin{array}{l}\text { n: } \\
\text { Politik nromosi nocisi }\end{array}$ & $\begin{array}{l}\text { Kelemahan: } \\
\text { 1. Moral dan komitmen karyawan } \\
\text { rendah } \\
\text { 2. Periode penyesuaian yang lama }\end{array}$ \\
\hline
\end{tabular}

b) Prinsip-Prinsip Perekrutan Pada dasanya setiap perusahaan memiliki prinsip di dalam merekrut karyawan barunya. Menurut Rivai Veithzal (2005), prinsipprinsip perekrutan ialah: 
- Mutu karyawan yang direkrut harus sesuai kebutuhan yang diperlukan.

- Jumlah karyawan yang diperlukan harus sesuai dengan job yang tersedia.

- Meminimalkan biaya yang diperlukan

- Perencanaan, Pertimbanganpertimbangan hukum, Fleksibility

\section{TRAINING}

Pelatihan sebagai wahana untuk membangun SDM menuju era globalisasi yang penuh dengan tantangan. Karena itu, kegiatan pelatihan tidak dapat diabaikan begitu saja terutama dalam memasuki era persaingan yang semakin ketat, tajam, berat pada abad milenium ini. Biasanya pelatihan merujuk pada pengembangan keterampilan bekerja yang dapat digunakan dengan segera.

\section{Mangkuprawira (2004),} "training atau pelatihan merupakan sebuah proses mengajarkan pengetahuan dan keahlian tertentu, serta sikap agar karyawan semakin termapil dan mampu melaksanakan tanggung jawabnya dengan semakin baik, sesuai dengan standar".

Rivai Veithzal (2005), "pelatihan ialah bagian pendidikan yang menyangkut proses belajar untuk memperoleh dan meningkatkan keterampilan di luar sistem pendidikan yang berlaku dalam waktu yang relatif singkat dengan metode yang lebih mengutamakan praktik daripada teori”.

Adapun manfaat dari training atau pelatihan menurut (Mangkuprawira, 2004) ialah sebagai berikut:

- Membantu menciptakan citra perusahaan yang lebih baik

- Menyediakan informasi untuk memperbaiki pengetahuan kepemimpinan, keterampilan berkomunikasi, dan sikap.

- Meningkatkan pemberian pengakuan dan perasaan kepuasan pekerjaan

- Mengembangkan jiwa untuk terus mau belajar

- Memperbaiki hubungan antara atasan dan bawahan

- Membantu dalam meningkatkan produktivitas dan kualitas kerja

- Membantu seseorang mengembangkan keterampilan berbicara 
- Membantu mengurangi rasa takut/khawatir dalam mencoba melakukan tugas baru.

\section{PEMBERIAN JAWAB \\ TANGGUNG}

Tanggung jawab adalah kesadaran manusia akan tingkah laku atau perbuatan yang disengaja maupun yang tidak di sengaja. Kata Tanggung jawab itu sendiri berarti siap menerima suatu kewajiban dan berani menerima risiko dari hasil tugas atau kewajiban yang akan dijalani, kata tanggung jawab sebenarnya sangatlah sederhana namun untuk melakukannya tidak semudah yang dibayangkan karena banyak dari manusia saat ini lebih memilih menghindari tanggung jawab daripada menerima tanggung jawab, mereka hanya memikirkan tentang haknya daripada kewajibannya.

Bagi seorang karyawan baru yang telah selesai pada program training (pelatihan), maka perusahaan akan mempercayakan atau memberikan tanggung jawab kepada karyawan tersebut. Yang dimaksud dengan pemberian tanggung jawab adalah pemberian tugas yang akan di lakukan oleh karyawan selama bekerja di perusahaan tersebut. Pemberian tanggung jawab kepada karyawan biasanya sudah diatur dalam ketentuan perusahaan, dan pemberian tersebut berdasarkan dibagian mana karyawan tersebut akan di tempatkan.

\section{KOMPENSASI}

Menurut Samsudin (2005), "kompensasi merupakan pemberian balas jasa, baik secara langsung berupa uang (finansial) maupun tidak langsung berupa penghargaan (nonfinansial)". Sedangkan menurut Hanggraeni (2012), "kompensasi atau compensation adalah segala sesuatu yang diterima oleh karyawan sebagai balas jasa yang diberikan oleh organisasi atas pekerjaan yang telah dilakukan".

Tujuan pemberian kompensasi menurut (Samsudin, 2005) sebagai berikut:

a) Pemenuhan Kebutuhan Ekonomi. Kompensasi yang diterima oleh karyawan dapat memenuhi kebutuhan hidup sehari-hari.

b) Meningkatkan Produktivitas Kerja. Pemberian kompensasi yang makin baik akan mendorong karyawan bekerja secara produktif.

c) Memajukan perusahaan. Semakin berani suatu perusahaan memberi kompensasi yang tinggi, menunjukkan betapa makin suksesnya suatu perusahaan.

d) Menciptakan Keseimbangan dan Keadilan. Bahwa pemberian 
kompensasi berhubungan dengan persyaratan yang harus dipenuhi karyawan sehingga tercipta keseimbangan antara input dan output.

\section{E. PROMOSI}

Promosi terjadi apabila seorang karyawan dipindahkan dari suatu pekerjaan ke pekerjaan lain yang lebih dalam pembayaran, tanggung jawab dan level. Umumnya diberikan sebagai penghargaan, hadiah (reward system) atas usaha dan prestasinya.

Nitisemito (2004), "promosi mempunyai arti penting bagi setiap perusahaan, sebab dengan promosi berarti kestabilan perusahaan dan moral pegawai akan dapat lebih terjamin".

Siagian (2006), "promosi terjadi apabila seorang pegawai dipindahkan dari satu pekerjaan ke pekerjaan lain yang tanggung jawabnya lebih besar, tingkatannya dalam hierarki jabatan lebih tinggi dan penghasilannya lebih besar".

syarat-syarat promosi adalah sebagai berikut:

a) Pengalaman. Dengan pengalaman yang lebih banyak diharapkan kemampuan yang lebih tinggi, ideide yang lebih banyak dan sebagainya. b) Tingkat pendidikan. Dengan pendidikan yang lebih tinggi maka seseorang akan lebih bertanggung jawab pada jabatan yang akan diberikan

c) Loyalitas. Dengan loyalitas yang tinggi dapat diharapkan antara lain tanggung jawab yang lebih besar.

d) Tanggung jawab. Sering kali suatu perusahaan diperlukan suatu tanggung jawab yang cukup besar, sehingga masalah tanggung jawab merupakan syarat utama untuk promosi jabatan.

e) Kepandaian bergaul. Misalnya jabatan untuk salesman adalah sangat penting untuk menetapkan kepandaian bergaul sebagai suatu syarat promosi jabatan.

f) Prestasi kerja. Pada umumnya setiap perusahaan selalu mencantumkan syarat untuk prestasi kinerjanya.

\section{HASIL PENELITIAN DAN PEMBAHASAN}

\section{Uji Kualitas Data}

\section{a. Uji Kuallitas Data}

\section{1) Uji Validitas}

Untuk mengetahui kelayakan butir-butir dalam daftar angket yang telah disajikan kepada responden maka diperlukan $\mathrm{Uji}$ Validitas sebagai berikut: 
Tabel 1. Uji Validitas

Item-Total Statistics

\begin{tabular}{|l|r|r|}
\hline \multicolumn{1}{|c|}{ INDIKATOR } & $\begin{array}{c}\text { Corrected Item- } \\
\text { Total Correlation }\end{array}$ & $\begin{array}{c}\text { Valid atau } \\
\text { Tidak Valid }\end{array}$ \\
\hline Perekrutan dan Training & .636 & Valid \\
Pemberian Tanggung Jawab & .575 & Valid \\
Kompensasi & .420 & Valid \\
Promosi & .481 & Valid \\
Efektivitas Kinerja Karyawan & .638 & Valid \\
\hline
\end{tabular}

Sumber data: Pengolahan SPSS

Pada tabel diatas dapat dinilai Corrected Item Total Correlation >0,30, dapat disimpulkan bahwa variabel perekrutan dan training (X1), pemberian tanggung jawab (X2), Kompensasi (X3), Promosi (X4), efektivitas kinerja karyawan (Y), yang telah disajikan pada responden adalah valid. Dengan demikian semua item pertayaan pada variabel (X1), (X2), (X3), (X4) dan (Y) dinyatakan layak digunakan dalam penelitian ini tanpa harus mengganti pertanyaan lain.

\section{2) Uji Reabilitas}

Reabilitas dari pertanyaan kuesioner yang telah diajukan oleh penulis kepada responden dalam penelitian ini akan terlihat pada tabel Item-Total Statistics.

Tabel 2. Uji Reabilitas

Item-Total Statistics

\begin{tabular}{|l|r|r|r|}
\hline \multicolumn{1}{|c|}{ INDIKATOR } & $\begin{array}{c}\text { Scale Mean if } \\
\text { Item Deleted }\end{array}$ & $\begin{array}{c}\text { Scale Variance } \\
\text { if Item Deleted }\end{array}$ & $\begin{array}{c}\text { Cronbach's } \\
\text { Alpha }\end{array}$ \\
\hline Perekrutan dan Training & 96.36 & 17.990 & .663 \\
Pemberian Tanggung Jawab & 106.48 & 31.343 & .673 \\
Kompensasi & 110.24 & 31.107 & .712 \\
Promosi & 129.52 & 28.843 & .690 \\
Efektivitas Kinerja Karyawan & 118.68 & 33.477 & .683 \\
\hline
\end{tabular}

Sumber data: Pengolahan SPSS

Pada tabel di atas dapat dinilai Cronbach's Alpha X1 (Perekrutan dan Training)

0.663>0,60 maka variabel (X1) dinyatakan handal atau reliable. X2 (Pemberian Tanggung Jawab) 0.673>0,60 maka variabel (X2) dinyatakan handal atau reliable. X3 (Kompensasi) 0.712>0,60 maka variabel (X3) dinyatakan handal atau reliable. X4 (Promosi) 0.690>0,60 maka variabel (X4) dinyatakan handal atau reliable. Y (Efektivitas Kinerja Karyawan) 0.683>0,60 maka variabel (Y) dinyatakan handal atau reliable. 


\section{Uji Asumsi Klasik}

a) Uji Normalitas

Tabel 3. Uji Normalitas

One-Sample Kolmogorov-Smirnov Test

\begin{tabular}{|l|r|r|r|r|c|}
\hline & $\begin{array}{c}\text { Perekrutan dan } \\
\text { Training }\end{array}$ & $\begin{array}{c}\text { Pemberian } \\
\text { Tanggung } \\
\text { Jawab }\end{array}$ & Kompensasi & Promosi & $\begin{array}{c}\text { Efektivitas } \\
\text { Kinerja } \\
\text { Karyawan }\end{array}$ \\
\hline $\begin{array}{l}\text { Kolmogorov- } \\
\text { Smirnov Z }\end{array}$ & .760 & .737 & 1.195 & .737 & 1.406 \\
\hline
\end{tabular}

a. Test distribution is Normal.

b. Calculated from data.

Untuk dapat lebih memastikan uji normalitas, dapat menggunakan kolmogrov smirnov. Dengan menggunakan kolmogrov smirnov dapat dilihat dengan jelas apakah model regresi memenuhi asumsi normalitas atau tidak. Tabel kolmogrov smirnov di atas ini menunjukkan bahwa angka > 0,05, maka data tersebut mengindikasi model regresi yang memenuhi asumsi normalitas.

Nilai signifikansi Perekrutan dan Training (X1) pada uji kolmogorov-smirnov adalah $(0.760>0.05)$, sehingga berdasarkan uji normalitas kolomogorov-smirnov data berdistribusi normal. Nilai signifikansi Pemberian Tanggung Jawab (X2) pada uji kolmogorov-smirnov adalah $(0.737>0.05)$, sehingga berdasarkan uji normalitas kolomogorov-smirnov data berdistribusi normal. Nilai signifikansi Perekrutan dan Training (X1) pada uji kolmogorov-smirnov adalah (1.195 > 0.05), sehingga berdasarkan uji normalitas kolomogorov-smirnov data berdistribusi normal. Nilai signifikansi Perekrutan dan Training (X1) pada uji kolmogorovsmirnov adalah $(1.406>0.05)$, sehingga berdasarkan uji normalitas kolomogorovsmirnov data berdistribusi normal.

b) Uji Multikolinearitas

Tabel 4. Uji Multikolinearitas

\section{Coefficients $^{\mathrm{a}}$}

\begin{tabular}{|l|r|r|}
\hline \multirow{2}{*}{ Model } & \multicolumn{2}{|c|}{ Collinearity Statistics } \\
\cline { 2 - 3 } & Tolerance & VIF \\
\hline (Constant) & .519 & \\
Perekrutan dan Training & .573 & 1.927 \\
Pemberian Tanggung Jawab & .833 & 1.746 \\
Kompensasi & 1.200 \\
\hline
\end{tabular}




\begin{tabular}{|l|l|r|}
\hline Promosi & .779 & 1.284 \\
\hline
\end{tabular}

a. Dependent Variable: Efektivitas Kinerja Karyawan

Pedoman keputusan berdasarkan nilai tolerance

Berdasarkan tabel di atas dapat dilihat bahwa angka VIF (Variance Inflation Factor) lebih kecil dari 10 antara lain adalah perekrutan dan training 1,927 < 10, pemberian tanggung jawab 1,746 < 10, kompensasi 1,200<10, promosi 1,284 < 10 . Untuk nilai Tolerance perekrutan dan training 0,519>0,10, pemberian tanggung jawab $0,573>0,10$, kompensasi $0,833>0,10$, dan promosi $0,779>0,10$ sehingga tidak terjadi multikolinieritas.

\section{c) Uji Heteroskedastisitas}

Hasil uji heteroskedastisitas dapat dilihat pada sebaran titik-titik yang tersebar secara acak baik diatas maupun dibawah angka nol dari sumbu Y menunjukkan tidak terjadinya heteroskedastisitas dalam model regresi.

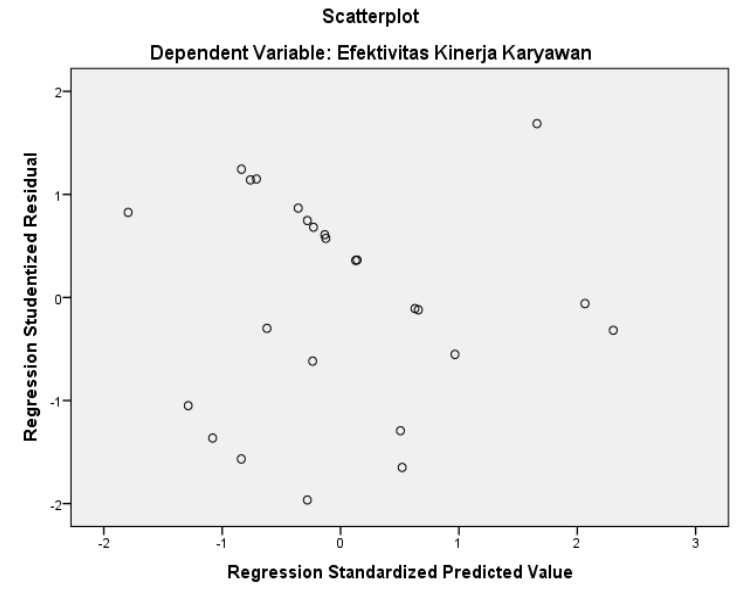

Gambar 1. Uji Heteroskedastisitas Sumber data: Pengolahan SPSS

\section{Uji Signifikansi Pengaruh Simultan (Uji F)}

Adapun hasil hipotesis berdasarkan Uji Serempak (F) dapat dilihat pada tabel dibawah ini. Bahwauji Anova atau uji Statistik F menghasilkan probabilitas signifikan jauh lebih kecil dari 0,05 yaitu 0,011 < 0,05. Maka model regresi dapat dikatakan bahwa terdapat pengaruh signifikan antara perekrutan dan training, pemberian tanggung jawab, kompensasi dan promosi terhadap efektivitas kinerja karyawan. 
Tabel 5. Uji Signifikansi Pengaruh Simultan

Uji F Statistik ANOVA $^{b}$

\begin{tabular}{|l|r|r|r|r|r|}
\hline \multicolumn{1}{|c|}{ Model } & Sum of Squares & \multicolumn{1}{|c|}{ Df } & Mean Square & F & Sig. \\
\hline Regression & 11.056 & 4 & 2.764 & 4.351 & $.011^{\mathrm{a}}$ \\
Residual & 12.704 & 20 & .635 & & \\
Total & 23.760 & 24 & & & \\
\hline
\end{tabular}

a. Dependent Variable: Efektivitas Kinerja Karyawan

b. Predictors: , Promosi, Kompensasi, Pemberian Tanggung Jawab, Perekrutan dan

Training

Sumber data: Pengolahan SPSS

\section{Uji Signifikansi Pengaruh Parsial (Uji t)}

Tabel 6. Uji Signifikansi Pengaruh Parsial

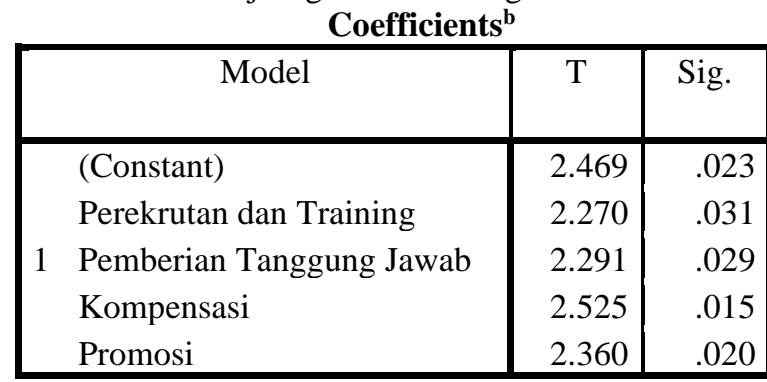

a. Dependent Variable: Efektivitas Kinerja

Karyawan

Sumber data : Pengolahan SPSS

Berdasarkan tabel di atas dapat dilihat bahwa:

1) Nilai probabilitas untuk variabel perekrutan dan training yaitu $0,031<0,05$ yang artinya terdapat pengaruh signifikan antara perekrutan dan training terhadap efektivitas kinerja karyawan.

2) Nilai probabilitas untuk variabel pemberian tanggung jawab yaitu sebesar 0,029<0,05 yang artinya terdapat pengaruh signifikan antara pemberian tanggung jawab terhadap efektivitas kinerja karyawan.

3) Nilai probabilitas kompensasi yaitu 0,015 $<0,05$ artinyaterdapat pengaruh signifikan antara kompensasi terhadap efektivitas kinerja karyawan.

4) Nilai probabilitas promosi yaitu $0,020<0,05$ artinya terdapat pengaruh signifikan antara promosi terhadap efektivitas kinerja karyawan perusahaan. 


\section{Koefisien determinan (R2)}

Tabel 7. Koefisien determinan

Model Summaryb

\begin{tabular}{|l|r|r|r|r|r|}
\hline Model & \multicolumn{1}{|c|}{$\mathrm{R}$} & R Square & Adjusted R Square & $\begin{array}{r}\text { Std. Error of } \\
\text { the Estimate }\end{array}$ & Durbin-Watson \\
\hline 1 & $.682^{\mathrm{a}}$ & .465 & .358 & .797 & 2.427 \\
\hline
\end{tabular}

a. Predictors: Promosi, Kompensasi, Pemberian Tanggung Jawab, Perekrutan dan Training

b. Dependent Variable: Efektivitas Kinerja Karyawan

Berdasarkan tabel di atas dapat dilihat bahwa angka Adjusted $R$ Square0,465 yang dapat disebut koefisien determinasi yang dalam hal ini berarti 46,50 efektivitas kinerja karyawan dapat diperoleh dan dijelaskan oleh Perekrutan dan training, pemberian tanggung jawab, kompensasi, dan promosi. Sedangkan sisanya 100\% - 46,50 \% = 53,50\% dijelaskan oleh faktor lain atau variabel diluar model misalnya, evaluasi kinerja karyawan, pengembangan karyawan, mutasi, displin, koordinasi, kompetensi karyawan, profesionalisme dan lain-lain.

\section{PENUTUP}

\section{SIMPULAN}

Berdasarkan penelitian yang telah dilakukan yang bertujuan mencari bukti empiris tentang hubungan antara perekrutan dan training, pemberian tanggung jawab, kompensasi, promosi terhadap efektivitas kinerja karyawan PT Pertani (Persero) Kantor Cabang Pemasaran Sumatera Utara, penulis menarik beberapa kesimpulan di antaranya:

1. Secara simultan, dapat disimpulkan perekrutan dan training, pemberian tanggung jawab, kompensasi, promosi berpengaruh signifikan terhadap efektivitas kinerja karyawan perusahaan. Artinya meningkatnya perekrutan dan training, pemberian tanggung jawab, kompensasi, promosi akan meningkatkan efektivitas kinerja karyawan.

2. Sedangkan secara parsial perekrutan dan training, pemberian tanggung jawab, kompensasi, promosi berpengaruh signifikan terhadap efektivitas kinerja karyawan.

3. Angka adjusted $R$ square atau koefisien determinasi adalah 0,465. Yang berarti 46,50\%, efektivitas kinerja karyawan dapat diperoleh dan dijelaskan oleh Perekrutan dan Training, Pemberian Tanggung Jawab, Kompensasi, dan Promosi. 


\section{SARAN}

Berdasarkan hasil simpulan tesebut, maka dapat disarankan hal-hal sebagai berikut:

1. Untuk meningkatkan efektivitas kinerja karyawan diperlukan adanya peningkatan perekrutan dan training, pemberian tanggung jawab, kompensasi dan promosi.

2. Responden pada penelitian selanjutnya hendaknya diperluas, tidak hanya dari lingkup pegawai tetap PT Pertani (Persero) Kantor Cabang Pemasaran Sumatera Utara saja tetapi responden seluruh karyawan pada perusahaan BUMN (Badan Usaha Milik Negara) lainnya.

3. Untuk peneliti selanjutnya hendaknya dapat mempertimbangkan untuk menambah variabel lain yang dapat mempengaruhi efektivitas kinerja karyawan.

\section{DAFTAR PUSTAKA}

Kaswan. (2012). Coaching dan Mentoring Untuk Pengembangan SDM dan Peningkatan Kinerja Organisasi. Bandung: Alfabeta.

Liliweri, A. (2017). Komunikasi Antar Personal. Prenada Media.

Nurdin, I., \& Hartati, S. (2019). Metodologi Penelitian Sosial. MEDIA SAHABAT CENDEKIA.

Pambudu, T. (2014). Budaya Organisasi dan Peningkatan Kinerja Karyawan. Jakarta: Bumi Aksara.
Sugiyono. (2014). Metode Penelitian Pendidikan Pendekatan Kuantitatif, Kualitatif, dan R\&D. Metode Penelitian Pendidikan Pendekatan Kuantitatif, Kualitatif Dan R\&D. 